\title{
Henry McDonald
}

\section{Language and being}

\section{Crossroads of modern literary theory and classical ontology}

\begin{abstract}
My argument is that poststructuralist and postmodernist theory carries on and intensifies the main lines of a characteristically modern tradition of aesthetics whose most important point of reference is not French structuralism - as the term, 'poststructuralism', implies - but the tradition of 18 th-century German romanticism and idealism that culminated in the work of Heidegger during the Weimar period in Germany between the world wars and afterward. What characterizes this modernist tradition of aesthetics is its valorization of language as a mode of being possessed of an 'ontological' status. I place the term 'ontology' in quotes in order to highlight the distinction between 'metaphysics', with its Aristotelian and neo-Platonic connotations of a 'chain of being', and the more modern term 'ontology', which was coined in the 17th century and which became widely used during the 18 th century by Leibnizian philosophers Christian Wolff and Alexander Baumgarten; the latter, not incidentally, also helped to establish modern usage of the term 'aesthetics'.

'Metaphysics' and 'ontology' have their roots, respectively, in those two most major currents of our western heritage, the Graeco-Roman and Judaeo-Christian. These currents, although inextricably linked to one another in innumerable ways, have nonetheless been engaged, as Nietzsche put it, 'in a fearful struggle on earth for thousands of years' that has been obscured by Heidegger's and Derrida's accounts of the history of western philosophy. Such accounts have projected what is basically a romanticist critique of Enlightenment values and thought on to a totalizing account of the history of Western thought since Plato. My purpose in emphasizing the distinction between metaphysics and ontology is to provide a conceptual framework within which our understanding of the development of modern aesthetics, and the concept of language that informed that development, can be related to the larger philosophical issues at hand. Literary theorists in
\end{abstract}

PHILOSOPHY \& SOCIAL CRITICISM • vol 30 no 2 • pp. 187-220

Copyright @ 2004 SAGE Publications (London, Thousand Oaks, CA and New Delhi)

wwW.sagepublications.com [DOI: 10.1177/0191453704041243] 
the United States, by endorsing Heidegger's and Derrida's self-serving accounts of their writings as assaults on the entire history of Western philosophy, and by failing to judge them critically as outgrowths of that history, have not only obscured these developments. They have also sustained the central tenet of American literary theory since the 1960s: that there is such a thing as a 'Western philosophical tradition' on the 'other' side of which, through an endless series of linguistic coinages and 'erasures', we may maneuver ourselves. My claim is that to the extent that there is such an other side, we are already on it, and that we fundamentally misunderstand our situation if we regard it as 'other' to the Western philosophical tradition.

Key words Derrida $\cdot$ Heidegger $\cdot$ language $\cdot$ ontology $\cdot$ theory

One of the remarkable features of the development of American literary theory since the 1960s has been its displacement of the term 'philosophy' by the term 'theory'. The sources of that displacement can be traced to the work of the thinker who, more than any other, shaped American literary theory during the period: Jacques Derrida. ${ }^{1}$ Only by distinguishing 'theory' from 'philosophy' - especially, as Derrida said, 'the history of philosophy' - could the epistemological stranglehold effected by the latter be broken. ${ }^{2}$ This distinction was taken, by American literary theorists, quite in the spirit it was given: as offering a way of 'theorizing' that would rise above and expose the futility of any merely 'philosophical' tradition, especially if that tradition were Anglo-American and analytic. New Critics, in contrast, had viewed literary theory as a province of aesthetics, which was, in turn, following the standard Kantian division, one of the three main subject-matters of philosophy, epistemology and ethics being the other two. ${ }^{3}$

To free theory from philosophy, however, literary theorists needed to break from the philosophical tradition of aesthetics and what they regarded as its 'meaning-oriented', epistemological basis. That break came to be signified by the term 'poststructuralism'. That the term was of American coinage and did not have a French equivalent or counterpart was crucial to the power it wielded. It was crucial because it allowed American critics to reference their theoretical orientation to a 'foreign' source, or tradition, which was largely of their own invention. For in France there was no distinct movement which came 'after' structuralism and which was regarded as its successor - even though, of course, there was a second generation of structuralists in the 1960s which radicalized the anti-humanistic orientation of the first generation. By the mid-1980s, moreover, many of the leaders of the second generation, including Barthes, Althusser, and Foucault, as well as Phillippe 
Sollers's influential journal Tel Quel, had disappeared from the scene and Derrida's influence in France, never very great to begin with, had waned. What came 'after' structuralism came not in France but in the United States where, however, there was no 'before', relative to poststructuralism, since structuralism was never well established enough here to justify speaking of it as being superseded. Structuralism, in sum, became influential in the United States only as poststructuralism, in which guise it could appear to be exactly what it was not in France: an anti-formalistic approach to literary study that encouraged political engagement. ${ }^{4}$

In this essay, I argue that the most important sources of contemporary American literary theory are neither the linguistics-based movement of French structuralism, as the term 'poststructuralism' implies, nor a 'modernity' that has been superseded, as the term 'postmodernism' implies, but rather a modernist tradition of aesthetics shaped by 18th- and early 19th-century German Romanticism and idealism, movements that culminated in the work of Heidegger during the Weimar period between the world wars and afterward, exercising an increasingly dominant influence on French theorists after the Second World War, from Sartre through Derrida, and subsequently on the development of poststructuralism and postmodernism during the 1970s and 1980 s in this country.

That deconstruction shares much in common with Romanticism is hardly an original observation. ${ }^{5}$ Nonetheless, the observation, when made, is not usually intended to apply to deconstruction's semiotic account of language as a system of arbitrary signs without positive values. For the latter account denies what Romanticism is often assumed to maintain: that the meaning of our language signs is grounded in some extra-linguistic, usually organicist 'presence' to which the signs refer. My contention, by contrast, is that Romanticist, especially German influences, operating in complementary relation with influences from the English and French Enlightenments, provided the cultural and conceptual milieu in which literary theory's 'ontological', but intensely antimetaphysical, view of language took root and grew. Far from militating against such a process, semiotics formed one of its more crucial components. In what follows, I explore what is at issue for literary theory in this process, beginning with an historical overview of the French and German sources of American literary theory.

\section{II}

The movement of French structuralism out of which American poststructuralism is supposed to have developed arose in the 1950s as a 
radical new method of sociological analysis that drew inspiration from the hard sciences, was modeled on Saussurean linguistics as shaped by Roman Jakobson and Claude Lévi-Strauss, and gained its greatest support in the areas of anthropology, psychoanalysis, and literary criticism. What was radical about the method was not just its overwhelming emphasis on language as the key to understanding thought and behavior in all areas, but its anti-humanistic, largely de-historicized conception of language as an arbitrary system of signs which operated independently of the control of an intentionalist subject, especially if that subject were an author. Such language-based anti-humanism not only challenged the Sartrean existentialism that had dominated Parisian intellectual culture since the Second World War, but was also a threat, within the French university system, to the methods and assumptions of the older, highly respected academic disciplines of philosophy and history, which until this time had successfully resisted, Durkheimian sociology notwithstanding, the incursions of the 'upstart' social sciences. In sharp contrast to poststructuralism in the United States, structuralism was a movement launched and sustained outside the privileged centers of the academy; not until the mid-1960s - Lévi-Strauss's first book was published in 1949 - did it become firmly entrenched within French academic life. ${ }^{6}$

Although many of the early structuralists were Hegelians and Marxists, the political orientation of the movement was far from 'radical' by French standards. On the contrary, one of its principal targets was the ethic of political and personal 'engagement' espoused by Sartre, whose thought and influence were attacked in the harshest and most uncompromising terms by much of the French structuralist movement, from Lévi-Strauss to Althusser, Foucault, Derrida, and Lyotard; only Roland Barthes, among major figures in the movement, spoke appreciatively of Sartre's work. When the student-led rebellion of May 1968 exploded, it took most structuralists by surprise, received little support from them with the exception of Foucault, and as a consequence earned the resentment of many of the students. Sartre, by contrast, dramatically championed their cause. ${ }^{7}$

During the 1960s, the leadership of the structuralist movement shifted to a younger generation of theorists led by Foucault, Barthes, Lacan, and Althusser. This generation escalated structuralism's antipathy to traditional philosophy, including Sartrean humanism, and shifted the register of its scientistic ambitions to a more recondite, philosophical and literary key. Most of the generation saw themselves less as breaking with structuralism than as developing and radicalizing its original goals. It is true that beginning in the late 1960s, many members of this generation, Derrida and Foucault included, sharply criticized earlier forms of structuralism, which were associated more than any 
other single figure with Lévi-Strauss, whose work Derrida critiqued in his first lecture in the United States in 1966. But it is also true that the younger generation, Derrida and Foucault included, had closely identified themselves with structuralism prior to this time. The conception of language that informed their work was indeed quite consistent with that of the older generation. Lévi-Strauss, arguing against Sartre, had contended that 'the dichotomous approach [used in semiotics] is in no way incompatible with dialectical thought, but clearly the contrary', ${ }^{8}$ and most second-generation structuralists followed suit. Both privileged language, or more generally signs, as autonomous systems whose workings could be described in terms of a logic of difference, and whose basis was the analytical tool of Saussurean binary opposition developed by Jakobson and Lévi-Strauss in the 1940s and 1950s. ${ }^{9}$

French 'poststructuralism', then, was viewed in France as at most a kind of 'hyper-structuralism' or 'neo-structuralism', as Manfred Frank has termed it, ${ }^{10}$ that was continuous with, even if diverging in significant ways from, the original structuralism of Jakobson, and Lévi-Strauss as influenced by the work of Saussure. If there was a significant and consistently maintained change in theoretical orientation from the first to the second generation of structuralists in France, it is best characterized less as a break or rupture from classical to modern philosophical conceptions than as a gradual change or transition within characteristically modern perspectives: from Hegelian, as well as Husserlian and early Heideggerian perspectives, to a late Heideggerian one. ${ }^{11}$

The influence of Hegelian dialectics and Husserlian phenomenology on 20th-century French thought can hardly be overestimated. ${ }^{12}$ French philosophy during the 19th century had been dominated by neoKantianism, which arose in Germany in the 1830s and 1840s as a 'back to Kant', anti-Hegelian movement that attempted to restore the boundaries between the sciences and the humanities, Naturwissenschaften and Geisteswissenschaften, and which in the process granted epistemological priority to the former. By the 1890s in France and elsewhere, a strong reaction against such positivistic currents had set in. ${ }^{13}$ But that reaction, fueled by the Dreyfus affair, drawing on Marx more as a moral authority than as a dialectician, and appealing to the Romanticist intuitionism of Henri Bergson, was anything but Hegelian in substance or spirit. As Mark Poster showed, only in the wake of the disillusionment after the First World War, during the 1920s and 1930s, did Hegelian and Marxist historicism become a major force in French intellectual life (which was exactly the period in Germany, we will see in a moment, when disillusionment with historical grand narratives reached crisis proportions). The appeal of both Hegelian dialectics and Husserlian phenomenology was that they seemed to offer methods and strategies to challenge and critique neo-Kantian and Enlightenment rationalism, 
and to do so in a way that had both philosophical and political ramifications. As Judith Butler said, referring to the sense of defeat and disillusion that characterized post-war France:

The Phenomenology's vision of an active and creating subjectivity, a journeying subject empowered by the work of negation, served as a source of hope during these years of political and personal crisis. The ontological principle of negation made itself known historically during these times as a principle of destruction, and yet Hegel's Phenomenology provided a way to understand negation as a creative principle as well. The negative is also human freedom, human desire, the possibility to create anew; the nothing to which human life had been consigned was thus at once the possibility of its renewal. ${ }^{14}$

It was in the work of the second generation of structuralists that such possibilities of nothingness took on new and energetic form. For such thinkers, who generally assumed as their point of departure Heidegger's 1947 critique of Sartrean humanism, as well as his lectures on Nietzsche's The Will to Power, it was the anti-rationalist, ontologically subversive implications of language which were most important. As Vincent Descombes described this process, 'It was necessary to abandon the concept in order to state the definitive issue - existence or non-existence, being or non-being'. ${ }^{15}$ Crucial in promoting such a turn away from epistemology to ontology were the seminars of Heideggerianinfluenced Hegelian philosophers Alexander Kojève and Jean Hyppolite. ${ }^{16}$ These seminars provided occasions for the presentation of important early writings of Lacan, Deleuze, Foucault, and Derrida. Applying the tools of Saussurean linguistics to Hegelian and Heideggerian thought, but rejecting the rationalist basis on which Saussure, influenced by 18 thcentury thought, had contrived those tools, these thinkers attacked the anthropomorphically driven presumption of language mastery which, they averred, had characterized the western philosophical tradition from its beginnings in ancient Greece. As Gilles Deleuze said, 'Philosophy must be ontology, it cannot be anything else; but there is no ontology of essence [i.e. classical ontology or metaphysics], there is only an ontology of sense'. ${ }^{17}$ By 'ontology of sense', Deleuze meant what Foucault, Barthes, and Derrida all referred to in different ways as the ontological, but determinedly anti-metaphysical, effort to think 'the being' of language. And to think the being of language was at the same time, as the Tel Quel group, influenced by the symbolist, surrealist, and dadaist movements, emphasized, to think of language as a performative medium which exemplified what was most crucial to the aesthetic experience. In this way an understanding of the logic of language as the product of arbitrary processes was joined to the aestheticist bestowal on language of a 'being' that is at the same time a 'nothingness' - a being of nothingness, a presencing of absence. As Descombes put it: 


\section{McDonald: Language and being}

In the portion of the world labelled 'History', negativity rules. Or, if we prefer, difference. If nothing is not being, and if 'to be' and 'to be identical with oneself' are identical, then nothingness is never identical with anything - never, nowhere, and in no case. But if nothingness has no identity, if it is only defined by difference, then nothingness must be said to be different from itself, there is a certain being in not-being. ${ }^{18}$

Eighteenth-century skepticism, which had questioned our direct access to reality on the basis of our dependence on the flawed instruments, especially language, by which such access could presumably be gained, thus installed itself as a key component of a 20th-century affirmation: that language, viewed now as the more or less exclusive basis of our access to reality, constituted a defining element of our being. Skepticism about the referential and representational properties of language silently merged with the assertion of language's autonomous character: its status as a form of being that rises above, or 'cancels and preserves' (aufgehoben), any merely 'human', sensuously grounded, social and historical form of experience. ${ }^{19}$

But what was, at least in the initial stages of French structuralism, a more or less 'stifled' current of opposition to Enlightenment rationalism had long before taken on, within the German tradition, the proportions of a raging flood. Although German intellectuals had always been lacking, relative to the French, in political avenues of expression, they had usually made up for such a lack by endowing less public and political forms such as literature and philosophy with culturally oppositional and nationalistic energies. During the 1890s, the German intellectual community, like the French, underwent a strong reaction against the heritage of 19 th-century neo-Kantianism. Unlike in the case of the French, however, that reaction resulted not in the adoption of an historicism that would temper the traditionally anti-historical esprit de géométrie of the French, but rather in the repudiation of a certain kind of historicism. For in 19th-century Germany, neo-Kantianism had acquired positivistic, relativist, and scientizing propensities that imbued later critics, from Windelband, Rickert, and Dilthey to Husserl and Heidegger, with a sense of 'the crisis of historicism'. That crisis became, during the Weimar period between the world wars, a crisis of German national identity which Heidegger universalized by giving ontological significance - by, in Nietzsche's words, 'projecting the conditions of existence as predicates of being in general' ${ }^{20}$ Whereas in France, to be 'historical' in a Marxian-Hegelian sense was to challenge, or at least qualify, the epistemological dominance of the natural sciences, in Germany to be 'historical' was to reinforce that dominance. The title of Hans-Ulrich Lessing's History as a Process of Conferring Meaning upon the Meaningless (1919), published one year after Spengler's The Decline of the West, says it all, or at least helps to explain why Heidegger, in 
common with many of his generation after the First World War, felt so strongly the need to recover another kind of history, one that he called 'historicity' and which would not be subject to the epistemological stranglehold of the sciences. And for that purpose it was necessary to re-think 'the being' of history, a re-thinking which, under the crisisdriven conditions of the Weimar Republic, could be ratcheted up, rhetorically, to 'the destruction of the history of ontology'. ${ }^{21}$

In understanding and assessing the philosophical sources of poststructuralism and postmodernism, then, two very different intellectual contexts need to be taken into account: the Weimar period in Germany between the two world wars; and the rise of structuralism in France during the 1950s and 1960s. Both of these contexts received a strong impetus from the thought of Heidegger. As Michael Roth said, 'the Heideggerian critique of humanism illuminates Hyppolite's abandonment of historicism. The path of his retreat would become well traveled by the 1960s, and Heidegger was the guide.'22 Although Sartre had drawn extensively on Heidegger's Being and Time (1927) to formulate his early philosophy of existentialism, he had not hesitated to give that work a humanistic reading quite different from Heidegger's purposes. Sartre's perspective, in this regard, and his development of an emphatically Marxist philosophy during the 1950s, as well as his willingness, along with many other French intellectuals of this time, to overlook or excuse Stalinist atrocities, must be understood against the backdrop of a French culture that had suffered a humiliating defeat at the hands of Nazi Germany. Indeed, the primary reason that the moral authority of the French Communist Party was so high after the war was that it had been one of the few groups in France actively to resist Nazism during the war, although only after Hitler's invasion of Russia in 1941.23

Yet by the 1960s the situation had changed dramatically. Not only had the second generation of French structuralists, especially Foucault and Derrida, grown increasingly disenchanted with Marxism - Foucault sarcastically described Sartre's Critique of Dialectical Reason, published in 1960, as 'the last great work of the 19th century'24 - but they also exhibited increasing admiration for the philosophy of a man who had been, for a short time, a member of the Nazi Party, and whose work, more importantly, had been put in the service of Nazi ideology by Heidegger himself. The question that cries out for an answer is: Why? What was it in Heidegger's work, especially in his late work, that so strongly appealed to French thinkers of this period that they were willing not just to break with the tradition of Cartesian and Enlightenment rationalism to which Marxian, Hegelian, and phenomenological thinkers such as Sartre and Merleau-Ponty had, in spite of everything, remained attached, but even to turn their backs on the virtually sacrosanct role of 
the French intellectual as spokesperson for the progressive and emancipatory values of western civilization?

\section{III}

The answer to this question, I submit, lies in that deep-seated ontological, but emphatically anti-metaphysical, urge that has increasingly driven humankind, since the 18th century, to redefine itself in linguistic terms. In the first section of this essay, I contended that the most important sources of contemporary literary theory are neither the linguisticsbased movement of French structuralism, as the term 'poststructuralism' implies, nor a 'modernity' that has been superseded, as the term 'postmodernism' implies, but rather a modernist tradition of aesthetics shaped by 18th- and early 19th-century German Romanticism and idealism. What characterizes this modernist tradition of aesthetics is its valorization of language as a mode of being possessed of an 'ontological' status. I place the term 'ontological' in quotes in order to distinguish between the ancient term 'metaphysics', with its Aristotelian and neoPlatonic connotations of a 'Chain of Being', and the more modern term 'ontology', which was coined in the 17th-century by an obscure Calvinist philosopher, and which became widely used during the 18th century by Leibnizian philosophers Christian Wolff and Alexander Baumgarten; the latter, not incidentally, also helped to establish modern usage of the term 'aesthetics'. ${ }^{25}$ 'Metaphysics' and 'ontology' have their roots, respectively, in those two most major currents of our western heritage, the Graeco-Roman and Judaeo-Christian. These currents, although inextricably linked to one another in innumerable ways, have nonetheless been engaged, as Nietzsche put it, 'in a fearful struggle on earth for thousands of years' ${ }^{26}$ Classical metaphysics may be distinguished from modern ontology by the former's lack of a distinct concept of 'existence' as radically contingent. ${ }^{27}$ Usually set in opposition to the Aristotelian and more rationalistic concept of 'essence', the notion of existence has its sources in the distinctively Christian account of creation ex nibilo. It was given special emphasis by Martin Luther during the Reformation and gained currency in modern times through the work of Søren Kierkegaard, which influenced Heidegger and other existentialist thinkers. ${ }^{28}$ By providing a counter-concept to 'presence', it has also influenced, less directly, poststructuralist and postmodernist thinkers. ${ }^{29}$

As I will use the terms in this paper, then, 'metaphysics' inherits the rationalistic emphasis placed on being by classical culture; it asks of the whatness or essences of things (ousia, essentia), such 'essences' forming a conceptually comprehensible, eternally self-generating hierarchy, or Chain of Being, in which the human essence occupies one, and not the 
highest, level. 'Ontology', on the other hand, signifies not metaphysics, but what Kant called a 'metaphysics of metaphysics' (my emphasis). It inherits the sense of radical contingency placed on being by Christian, especially Lutheran, theology, asking of the thatness or 'existence' of things (existentia), an existence not comprehensible in human terms but whose mystery human being is uniquely qualified, by virtue of its capacity for language, to engage with. Whereas classical metaphysics declares, ex nibilo nibil fit ('from nothing, nothing comes to be'), Christian thinkers such as Augustine maintain, ex nibilo fit - ens creatum ('from nothing comes created being'). Pre-Christian metaphysics asks, 'What is?' Post-Christian ontology wonders that there is anything at all and poses the question, originating with Leibniz but taking on its distinctively modern implications with Hume, Schelling, and Heidegger, 'Why is there something rather than nothing?' 30

The latter question is distinctively modern because the mere asking of it throws us into a 'hermeneutic circle' which is not only inescapable but imposes on us a skeptical doubt about 'the reality' of what lies outside us; it imposes a view of ourselves from within as stretched between a dialectical, but at the same time a dialectically unresolvable, tension of being and nothingness. That tension subsists on, and is continuously incited by, the threat of nihilism. Such a threat, as Karl Lowith pointed out, could have arisen in radical form only in the context of the Christian notion of creation ex nibilo, for only those who believe they have been created out of nothing are likely to be haunted by the contingency that they may become nothing once again. In 'What is Metaphysics?', Heidegger acknowledges his indebtedness to the old formula of Christian metaphysics, ex nibilo ens qua ens fit ['from the nothing all beings as beings come to be']. ${ }^{31}$ By contrast, the ancient Greeks and Romans, with their assumption that the universe was uncreated and eternally self-subsistent, were unaware of, or in any case indifferent to, the radical threat of nihilism. ${ }^{32}$

Such 'complacency of being', although in tension with Christian teachings from the beginning, received its most radical attack only with Martin Luther's campaign to 'destroy' Christian theology, a campaign that directly influenced Heidegger's project to 'destroy the history of ontology'. ${ }^{33}$ Luther's campaign took aim at the central basis of the classical, especially Aristotelian metaphysics inherited by Christianity: its understanding of the cosmos as a perpetually self-generating text that could be 'read' literally or allegorically from nature. Influenced by William of Ockham's nominalism, Luther viewed the 'book of nature' as essences 'in name only' and not, as in classical allegoresis, 'real'. What was 'real', rather, was a power of existence, a force of creation, 'behind' and wholly independent of the language in which external nature speaks to us. Such 'power of existence' was attributed to the power God had 
exhibited in creating the universe as well as to the holy Scriptures that were the direct expression of that creation. ${ }^{34}$ During the 16th and 17th centuries, moreover, such power of existence became associated with another sort of 'creation' also recounted in the Bible: Adam's ability to create language in accordance with his direct insight into the essential natures of words. But it was not until the 18th-century debates on 'the origin of language' engaged in by a host of English, French, and German thinkers that Adam's language-creating capacity gradually shed its divine origin and became widely associated with a non-naturalistic, reflective capacity, termed by Locke 'reflection', by Condillac 'reflexion', and by Herder 'Besonnenheit', that was viewed as characteristic of humankind in general. Whereas 17 th-century thinkers had assumed that the 'essences' of things pre-existed their expression in language, 18thcentury thinkers, led by Locke and Condillac, generally countered or at least qualified this assumption by granting language a formative role in the origin of the categories of rational thought. ${ }^{35}$

The feature that enabled language to take on such a formative role was the arbitrary nature of signs. Such arbitrariness, as Jonathan Culler observed, applies not just to the signifier, or sensory symbol; taken in that limited sense, many pre-modern and classical thinkers also held to 'the arbitrary nature of the sign'. ${ }^{36}$ What distinguishes modern accounts is the contention that not just the signifier, but also the signified, or meaning, is arbitrary. Language is no longer seen as reflecting a fixed basis of being. Rather, it gives expression to a capacity that frees our concepts and meanings from the static order of 'mere' nature and attaches them to arbitrary signs whose operations reflect a non-natural, distinctively human order of being. It is precisely that capacity which we dignify ontologically by the term 'existence'. Modern ontology, and the valorization of language that characterizes it, thus differ from all previous ontologies and systems of metaphysics in that they foster a skepticism about the mimetic or representational properties of language which simultaneously release into textual play human creative energies. At issue is not the superficial skepticism that denies reason or imputes an irrationality to human nature, but rather the form and shape reason takes given the fact that our 'essence' is formed by language. When Derrida, for example, makes the at first sight paradoxical claim that 'writing' (écriture) preceded speech, he is making an argument continuous with the debates on the origin of language during the 18th century: that language is so important to the very 'being' of humankind that it defines the nature of reason and must therefore be given logical priority over it. Language, the act of language, precedes essence, to adapt the Sartrean dictum. That is why Derrida's notion of text must be understood, in the words of Rodolphe Gasche, 'as an attempt to come to grips with the Heideggerian question of Being. What Derrida 
thus calls the text, instead of being governed by Being, makes Being a function of the general text'. ${ }^{37}$ Gianni Vattimo, similarly, emphasizes that Derrida's notion of differance 'is very far from signifying any decline in or exhaustion of the idea of ontological difference put forward by Heidegger'. ${ }^{38}$ Or Judith Butler, speaking of the rhetorical 'violence' so often effected by 'excitable speech', asks: 'Could language injure us if we were not, in some sense, linguistic beings, beings who require language in order to be? Is our vulnerability to language a consequence of our being constituted within its terms?'39

Such an understanding of language as a mode of being constitutes what I call an 'ontology of reflection' in contrast to the 'metaphysics of presence' that typified pre-modern, essentialist accounts of language. My purpose in introducing this terminology is not just to reinforce the distinction between 'metaphysics' and 'ontology', but to provide a conceptual framework within which our understanding of the development of modern aesthetics, and of the concept of language which informed that development, can be related to the larger philosophical issues at hand. It is not coincidental, in this regard, that it was the same philosopher, Immanuel Kant, who wrote the single most influential critique of classical metaphysics, The Critique of Pure Reason, and the single most influential treatise of modern aesthetics, The Critique of Judgment. The rise of modern aesthetics can be traced from Baumgarten's work and its antecedents in the 17th and 18th centuries through that of Condillac, Diderot, Rousseau, Hamann, Herder, Humboldt to Kant; and, from Kant to Schiller, Schelling, Hegel, and Coleridge - whose work, along with that of Victor Cousin, Mme de Stael, and later Carlyle, had such a decisive influence in this country, particularly on Poe and Emerson, and later on New Critics. By distinguishing between a premodern metaphysics of presence and a modern ontology of reflection, I am suggesting, the rise of modern aesthetics gains a greater philosophical coherence by being viewed against the backdrop of a radically new idea of 'reality', one that did something that classical metaphysics, the metaphysics of presence, had never done; it invested language with ontological significance.

To emphasize this disjuncture, I will use the terms 'metaphysics of presence' and 'ontology of reflection' in opposition to one another, even though we should keep in mind that they are interdependent and that in fact modern ontology carries with it many pre-modern, metaphysical resonances while ancient metaphysics carries with it many modern, ontological resonances. My use of the terms is adapted, of course, from the writings of Heidegger and Derrida, and is consistent with many aspects of their analyses, if not with their terminologies or, more fundamentally, with their philosophical approaches. Derrida, for example, referring to his term 'deconstruction', remarks: 
It was a kind of active translation that displaces somewhat the word Heidegger uses: 'Destruktion', the destruction of ontology, which also does not mean the annulment, the annihilation of ontology, but an analysis of the structure of traditional ontology. 40

In a note to 'Violence and Metaphysics', Derrida traces where such a 'non-annulment' of, or overcoming of metaphysics from within, was to lead Heidegger:

After desiring to restore the properly ontological intention dormant within metaphysics, after having reawakened the 'fundamental ontology' beneath 'metaphysical ontology', Heidegger, faced by the tenacity of traditional ambiguity, finally proposes to abandon the terms 'ontology' and 'ontological' (Introduction to Metaphysics). The question of Being cannot be submitted to an ontology. 41

Gilles Deleuze, similarly, distinguishes between traditional metaphysics and modern ontology by associating the former with 'essence' and the latter with 'sense'. Referring specifically to Jean Hyppolite's Heideggerian reading of Hegel in Logic and Existence, which also strongly influenced Derrida, Deleuze says:

The external difference between reflection and being is the internal difference of Being itself, in other words, Being identical to difference, identical to mediation. Being, according to Hyppolite, is not essence, but sense, it refers to being not as the essence beyond the appearance, not as a second world which would be the intelligible world, but as the sense of this world. Kant, however, is still the one most responsible for the substitution, because the critique replaces the being of the possible with the possibility of being; in short, essence with sense. That there is no 'beyond' means that there is no 'beyond' of the world and that in the world there is no 'beyond' of thought (because being thinks itself in thought). Finally, it means that in thought itself there is nothing beyond language. ${ }^{42}$

What both Derrida and Deleuze are getting at, in the above passages, is something very much like Kant's use of the phrase 'the metaphysics of metaphysics', to connote a new form of ontology. Nonetheless, neither Derrida nor Deleuze distinguishes consistently between 'metaphysics' and 'ontology' in the way I am proposing, but on the contrary they often use the terms synonomously to refer to an understanding of Being, and of the language in which Being has been forgotten, that is characteristic not just of classical but of modern times as well. Unlike Schelling, as Peter Dews has argued, 'deconstruction often prefers to forget that the linguistic character of being also implies the ontological character of language'. ${ }^{3}$ By providing what, in my terminology, is an 'ontological' critique of 'metaphysics', yet at the same time conflating the two terms, Heidegger and Derrida are enabled to have it both ways; they can provide a radical critique of western metaphysics without giving their own 
positions a positive content that would make them vulnerable to countercritiques. The results, without doubt, have been polemically effective. But they have also had the effect of obscuring understanding of the central philosophical 'event' of our time: the emergence of language as a form of being. They have obscured such understanding by conflating modern and pre-modern understandings of language: by projecting what is basically a Romanticist critique of Enlightenment values and thought onto a totalizing account of the history of western thought since Plato. ${ }^{44}$ By contrast, I maintain, in general agreement with Nietzsche, that in the centuries-old conflict between the metaphysics of presence and the ontology of reflection, a decisive although perhaps not final victory was gained in the 18th century for the latter, and that the works of Heidegger and Derrida, as well as those of most modern philosophers, including Nietzsche's, are heir, willingly or not, to this victory.

Poststructuralist and postmodernist thinkers, for all the sophistication of their semiotic account of language, have failed to grasp the significance of their own 'linguistic turn'. ${ }^{45}$ For what this phrase is sometimes taken to imply is that language and being are somehow at odds with one another, as though language represented a sphere or dimension beyond being or 'irreal'. But the shift that was set into motion by the Reformation and which reached maturity, though not finality, in Romanticism was a linguistic turn only in a secondary sense; more fundamentally, it was an ontological turn in which a metaphysics of presence based on rational essences gave way to an ontology of reflection based on contingent being. Such a turn was the product of a certain historical development, and in no sense the source of that historical development, as Heidegger maintained. ${ }^{46}$

\section{IV}

Among the factors obscuring our understanding of the emergence of language as a form of being - of the displacement of homo sapiens by homo textilis - is a conceptual polarization which, although certainly not invented by contemporary literary theorists, has been perpetuated by them: the polarization between the Enlightenment and Romanticism. As scholars have long argued, the developments of German Romanticism and idealism were strongly influenced by the English and French 'Enlightenments' through their roles, among others, in challenging classical conceptions of language. In disparaging Enlightenment thought and privileging, at least implicitly, Romantic thought, contemporary theorists not only underestimate and undervalue our debt to Enlightenment thinkers, but misunderstand and oversimplify the nature of Romanticism itself. ${ }^{47}$ 
The sources of such misunderstanding may be deemed 'ideological', in the sense in which Jerome McGann has applied this term to an earlier generation of scholars in The Romantic Ideology. That generation privileged 'unity of being' and 'harmony of differences' as definitive of the nature of Romanticism. ${ }^{48}$ Yet, as McGann argued, if romantic thinkers were influenced by pre-modern, as well as by 16 th- and 17 th-century organicist views of language, that influence was by no means hegemonic and was in any case, I would add, complemented by the more general influence of natural law and social contract theory. The latter treated social phenomena, including language, not just as 'artificial' constructs but as the products of an autonomous 'second nature', or human reflective capacity, that appealed to aesthetic experience and modeled itself on the example of verbal language, especially poetry. Indeed, the concept of the Aufhebung was applied to aesthetics long before it became the leading concept of German idealism in Hegel's philosophy; it plays a significant role, for example, in Kant's exposition of the 'dynamically sublime' in the Critique of Judgment $(106,121) .{ }^{49}$

Contemporary critics and theorists who describe 'disunity of being' and 'non-resolution of difference' as characteristically anti-Romanticist oversimplify the complexity of these concepts and betray an ideological bias no less pronounced than that of earlier generations, for such 'disunity' and 'non-resolution' are clearly extensions of a dialectical mode of thinking that originated with Romanticism; they are expressions of what Tzvetan Todorov calls a 'romantic spirit that enthrones difference in the place of identity'. ${ }^{50}$ Could it be that even in the 21 st century we have not left behind entirely that 'other' age, the Age of Romanticism - not to mention, the age of modernism? Jean-François Lyotard hints as much in The Postmodern Condition; and Philippe LacoueLaBarthe and Jean-Luc Nancy, two thinkers closely associated with Derrida, make the case emphatically in The Literary Absolute. Certainly there are few major themes of modernism and postmodernism that were not explicitly anticipated by Romanticist and idealist thinkers. ${ }^{51}$

What needs to replace the very broad and over-simplifying distinction between the 'Enlightenment' and 'Romanticism' is a more complex and nuanced set of distinctions, or rather entanglements, between French, German, English, and American traditions of thought. Chief among such entanglements, for the purposes here, is that between the French and German traditions, traditions which have become closely linked to one another by the very extremity of their differences. As observers of the French scene have long noted, the history of French philosophy since the early 19 th century has largely been the history of its use of German sources. ${ }^{52}$ Poet Heinrich Heine, who studied with Hegel and who, in common with an admirer of Heine, Nietzsche, was a francophile who detested much of German culture, put it this way in 
1831: 'great France has never been a fitting abode for philosophy, which perhaps will never flourish on French soil'. ${ }^{53}$ Heine's point was that the French have drawn so heavily on German philosophy not, of course, because they are themselves lacking in intellectual sophistication, but because such sophistication is of a very different kind from that of the Germans. As Lewis White Beck showed in his classic Early German Philosophy, the impact of the natural sciences was felt much later in Germany than in France and England. ${ }^{54}$ As a consequence, Germany's response to that impact, from Kant's three Critiques to Hegel's philosophy of history to Heidegger's 'destruction of the history of ontology', was more systematic and considered. During the period from 1770 to 1840 especially, the Germans served as what H. Stuart Hughes called 'the [philosophical] schoolmasters of Europe'. ${ }^{55}$ They served, most especially, as developers and systematizers of a modern philosophy of aesthetics that rejected the classical, ultimately Aristotelian theory of artistic mimesis and defined its subject-matter as quite distinct from, even opposed to, those of moral philosophy and epistemology. Here, as so often is the case, Kant is the crucial figure. Just as in his first two Critiques Kant separated morals from the theory of knowledge in order to grant the former its own distinctive kind of knowledge in its own separate sphere, so too in the Critique of Judgment Kant separated aesthetics from morals in order to grant the former its own autonomous basis. ${ }^{56}$ Yet the arguments given for such autonomy were by no means original to Kant or even to German philosophy in general; many of their essential features had been anticipated by a long line of English, French, and Italian thinkers of the 17th and especially 18 th centuries. The vital role that German thought played in the development of modern aesthetics consisted less in the originality of its contributions than in its genius for systematizing and rationalizing a province of human experience that had more commonly been treated prior to the late 18th century as incapable of systematization and rationalization. During the 16th century, Martin Luther had advanced a 'double-truth' doctrine that opposed reason and faith not as knowledge and belief but as two different forms of knowledge; the basis of such a doctrine, as Frederick Beiser showed, was not 'irrationalist' but on the contrary served as a crucial source of the rationalist movements of the English Enlightenment during the 17 th century. ${ }^{57}$ The same is true of the development of modern aesthetics during the 18 th century, a development made possible by an understanding of aesthetic experience not as 'non-rational' but as constituting its own kind of reason, or what Baumgarten called 'sensate cognition'. For example, the importance and appeal of Coleridge's notion of 'the suspension of disbelief', which was directly influenced by the work of Kant, Schelling, and Schiller, is that it gave expression to this new ontological, non-metaphysical conception of aesthetics; and 
hence laid the ground for the preoccupation with language that has characterized much of modernity since the 18th century.

Writing in 1831, Heine prophesied darkly a 'German revolution' that would complement the French revolutions of 1789 and 1830, and which would 'concern the whole human race'. ${ }^{58}$ Heine's prophecy was realized with consequences more grim than he, or Nietzsche, predicted, during the Weimar era and afterward when many of Germany's leading intellectuals, or 'mandarins', in Fritz Ringer's apt term, capitulated to the forces of the 'New Romanticism' and the 'conservative revolution' that was effected in its most extreme form by the Nazis. ${ }^{59}$ Among those intellectuals, was, of course, Martin Heidegger, arguably the 20th century's most influential philosopher, who was himself quite cognizant of the influence of his own work on the French. As he said, in an interview with Der Spiegel, 'When [the French] begin to think, they speak German; they say definitely that they would not manage it in their language'. ${ }^{60}$

There is, perhaps, some limited amount of truth in what Heidegger says here, but it gives a very distorted picture of the relation between French and German cultures if it is not also emphasized that 18thcentury German Romanticism and idealism were fed by the very French and English sources they were reacting against. Indeed, it might even be said that contemporary 'anti-humanism', which has its sources in Heidegger's 1947 essay, 'Letter on Humanism', is indebted to the tradition of 'humanism' - to the Renaissance tradition, that is, of studia bumanitatis, which denoted, according to Paul Oskar Kristeller, neither 'a philosopical tendency' nor 'a system', but rather a type of 'literary' and 'rhetorical' study 'as old as the Greek Sophists'. ${ }^{61}$ It follows that in recognizing the Romanticist sources of our current view of language we also draw on and adapt, rather than simply dismiss, the rationalist and humanist elements of that Romanticism. ${ }^{62}$ We must appreciate critically the tradition of German idealism and Romanticism to which Heidegger and Derrida owe so much and at the same time find within that tradition a countervailing rationalism and humanism to which these philosophers, along with many contemporary literary theorists in this country, have failed to do justice.

My chief illustrations of the value of pursuing such a strategy, which I can do little more than mention here, are the mature philosophies of Nietzsche and Wittgenstein, philosophies which, like those of Heidegger and Derrida, must be understood as arising within the analyticcontinental divide and not at either one of its poles. Both Nietzsche and Wittgenstein absorbed elements of the British philosophical tradition through their common debt to the work of Arnold Schopenhauer, that most 'analytical' of German philosophers; and both, even more importantly, wrote first books that exhibited philosophical tendencies and 
concerns similar to those of Heidegger and Derrida, but reacted sharply against those tendencies in their later writings. The early works, Nietzsche's The Birth of Tragedy and Wittgenstein's Tractatus LogicoPhilosophicus, were strongly influenced by Schopenhauer's anti-Hegelian, Kantian-based effort to 'sublime' art, especially music, by granting it a status out of reach of ordinary reason. By contrast, their later writings, including the 1886 preface to The Birth of Tragedy and the Philosophical Investigations, reject their own earlier 'absolutizing' tendencies, which Wittgenstein termed a need 'to sublime the logic of language' $(89,94)$ and Nietzsche a desire for 'otherworldly comfort'. ${ }^{63}$

Such similarities and differences between the two pairs of thinkers provide not just a basis of comparison, but also grounds for 'confrontation'. In particular, Heidegger's distorted reading of Nietzsche in lectures delivered from 1936 to 1940, but not published until 1961, which are the implicit and in some cases explicit basis of poststructuralist and postmodernist readings of Nietzsche, ${ }^{64}$ must be supplanted by a 'Nietzsche' very much at odds with Heidegger, a Nietzsche who sharply reacted against his Lutheran heritage and who was at home, as Heidegger was not, with the anti-Romanticist and anti-Christian values of classical Rome and the Enlightenment.

A similar kind of confrontation, somewhat less antagonistic but still significant, provides the context for a comparison of the thought of Derrida and Wittgenstein, the important point of difference being Wittgenstein's 'analytic' habit of imaging language as spoken rather than textual. Richard Rorty has argued that the early Wittgenstein, the Wittgenstein of the Tractatus, is relatively close in philosophical perspective to the late Heidegger, but that Wittgenstein's late writings diverge sharply from the latter. ${ }^{65}$ It seems to me that this is exactly right and that a parallel argument can be made about the relation between Nietzsche and Heidegger. It is Nietzsche and Wittgenstein's naturalistic and ethically based accounts of language as a finite, 'spatial and temporal phenomenon', in Wittgenstein's phrase, ${ }^{66}$ that make their works alternatives to - and not, as they are often misjudged to be, supports for - the sterility and formalism of poststructuralist and postmodernist anti-humanism.

\section{V}

During Heidegger's debate in Davos, Switzerland, with neo-Kantian philosopher Ernst Cassirer, a debate which took place in 1929, shortly before Heidegger was to join the Nazi Party and Cassirer to be exiled from Germany, a member of the audience asked: 'Since both men [Heidegger and Cassirer] speak a completely different language, could 
not an attempt at translation be made by both?' Cassirer's response to this request was long and painstaking. Heidegger, however, replied as follows: 'I believe that what I describe by Dasein does not allow translation into a concept of Cassirer's. ${ }^{\prime 67}$ Karl Lowith, who studied with Heidegger, identified the source of such intolerance as follows.

The basis that serves as the background for everything said by Heidegger, and that permits many to take notice and listen attentively, is something unsaid: the religious motive, which has surely detached itself from Christian faith, but which precisely on account of its dogmatically unattached indeterminancy appeals all the more to those who are no longer faithful Christians but who nonetheless would like to be religious. ${ }^{68}$

It is the weight of the 'unsaid' which, in Heidegger, provides the ballast and deep persuasiveness of everything which is merely voiced or articulated: the unfathomableness and infinite resonances silently set into motion by that Question of Being whose whole point, or raison d'être, is that it cannot be answered. Yet that unfathomableness, that mystery, as it takes shape and is developed by Derrida - who, in this sense, is Heidegger's true and authentic disciple - is attached not to the unarticulated, non-verbal realm of action and experience, as was the case with traditional forms of mysticism. Rather, it is attached to the text, to the written word, above all to the idea of textuality which, through the genius of deconstruction, is made to resonate with all the indeterminateness and undecideability that had attached to the merely unspoken. Its model is the valorization of the Bible by Luther, which initiated a distinctively German tradition whose essential features are described by Nietzsche:

How little German style has to do with sound and the ears is shown by the fact that precisely our good musicians write badly. The German does not read aloud, not for the ear but only with the eye; meanwhile his ears are put away in a drawer. In antiquity men read - when they did read, which happened rarely enough - to themselves, aloud, with a resounding voice; one was surprised when anyone read quietly, and secretly asked oneself for the reasons. With a resounding voice: that means, with all the crescendos, inflections, and reversals of tone and changes in tempo in which the ancient public took delight. In Germany the preacher alone knew what a syllable weighs, or a word, and how a sentence strikes, leaps, plunges, runs, runs out; he alone had a conscience in his ears, often enough a bad conscience; for there is no lack of reasons why Germans rarely attain proficiency in rhetoric, and almost always too late. ${ }^{69}$

Nietzsche's comments are illuminating when one considers that it was in Germany that the academic lecture attained its highest development; for the 'lecture' was precisely that form designed to subordinate the spoken word to the written text. As Peter Szondi commented: 
Even in Hegel's time lectures were still based on one's own or someone else's compendium. The purpose of lectures was not to transmit knowledge - that function was and is performed incomparably better by books. Rather they were designed for the elucidation and discussion of a text that lay before everyone in the audience. ${ }^{70}$

In his valuable book, Jeffrey Herf, consistently with Theodor Adorno and Pierre Bourdieu's earlier critiques of Heidegger, situates Heidegger's thought within the context of what he calls 'reactionary modernism', which he defines as a rejection of Enlightenment reason together with an acceptance of certain effects of modernity (technology) and the harnessing of such effects to anti-Enlightenment, irrationalist purposes. ${ }^{71}$ Viewed from a Nietzschean perspective, we might add that such a paradoxical enterprise is motivated at bottom by a slave-moralistic effort to reconstitute existence in the form of an 'other' metaphysics, or ontology of existence, that culminates in the investment of language with a sort of sacred status. What is provided in the process is ontological asssurance, 'metaphysical comfort' (in Nietzsche's phrase), together with epistemological aggression. The two facets, ontological asssurance and epistemological aggression, are most deeply characteristic of Heideggerian thought. Together, they enable us to understand Heidegger's appeal to poststructuralist and postmodernist theory: its uncanny combination of Romanticism and skepticism, a combination whose antecedents can be clearly traced to the German reaction against the Enlightenment: its employment of a radical skepticism (Hume, Spinoza) in the service of romantic, other-worldly ideals (Hamann, Jacobi).

Derrida, of course, cannot in any way be associated with Nazism or fascism. Nonetheless, his lengthy 'deconstruction' of Heidegger, Of Spirit, in which he places Heidegger's active and substantively philosophical involvement with Nazism on the same level as the misuse - and Derrida agrees that it was a misuse - of Nietzsche's writings by the Nazis, signifies a failure of ethical and political responsibility, if not, indeed, a lapse of intellectual integrity, that has not failed to disturb other French intellectuals such as Jean-François Lyotard, who describes the latter failure as a product of 'the deconstructive anamnesis, the blind blank zone'. Alluding to Heidegger's 'silence' on the Holocaust, and Derrida's discussion of that silence in Of Spirit, Lyotard speaks with a ferocity of sarcasm and moral indignation that are conspicuous by their absence in the public discourse of American literary theorists:

Such is the gesture of deconstruction that it impedes or mesmerizes itself. Freed of its onto-theological trappings (and of ethics, which is then only one of its aspects), this question 'finally' gives and poses itself with Heidegger, as it had been posing itself from the beginning, as he says. And this 'finally', adds Derrida, is without end. 'Posing' the question correctly consists in detecting in the metaphysical text, and even in the existential-ontological 
one, the signs, the slightest signs, of the lack of Being, which are the signs that Being makes. One deconstructs, then, because everything is badly constructed. Instead of analyzing the great, inauthentic, blind constructions, one sifts through and disperses the frail ruins through which Being (that is, nothingness) can, for a moment, introduce its dying light. When this meticulous and admirable archaeologist comes across the ashes of the Holocaust, how could he be surprised? Has he not always known that the 'spirit' of metaphysics builds its edifices on the denial of Being, on its Verneinung, and that they are promised to the Vernichtung, the annihilation, to the ashes by the retreat of Being? Only this one piece of bad news might disturb him, namely, that the master-deconstructor, the foreman of the post-philosophical excavation, has lent to extermination not his hand and not even his thought but his silence and nonthought. That he 'forgot' the extermination. ${ }^{72}$

Lyotard's reaction, in Heidegger and the Problem of the Jews, from which the above quote is taken, to the revelations of Heidegger's Nazism renewed during the 1980s, when the movement of French structuralism had lost most of its strength, was indeed more typical of the rhetorical violence with which many French intellectuals reacted during this period than was Derrida's tepid response in Of Spirit. But what is even more striking is that in the United States, where the movement of poststructuralism never really died but was transmuted into postmodernism and cultural studies, it has been Derrida's lead, rather than Lyotard's, which has for the most part been followed. This may account for why there is still such reluctance, among critics in the United States, to acknowledge that Heideggerian philosophy has substantive links to the crisis of historicism which preoccupied Weimar Germany and which led many of its leading intellectuals to capitulate to fascism. And if Heideggerian philosophy is implicated in this way, then so too are many currents of poststructuralism and postmodernism - not necessarily politically, but philosophically, intellectually, ethically. It is a complicity from which very few of us can claim to be excluded - and certainly not someone drawing on the thought of Nietzsche and Wittgenstein, thought which has a kinship, however uncomfortable, with that of Heidegger and Derrida.

In his portrait of the Apostle Plotinus Plinlimmon in Pierre, Herman Melville satirizes a certain tendency of American culture applicable as well to modern literary theorists. Plinlimmon's philosophy revolves around a contrast between our imperfect worldly 'horological' time and the ideal 'chronometric' time of heaven - in Kantian terms, between phenomenal and noumenal spheres. But the crucial feature of the logic of these two spheres is that precisely because they are so absolutely contradictory they are absolutely consistent with one another: 'By their very contradictions they are made to correspond'. Melville identifies here a kind of logic that may be seen as the culmination of the historical 
development from allegoresis to modern symbolism, in which a dualism constrained by the hierarchical metaphysics of the chain of being gives way to a more radical dualism characteristic of modern ontology's binary opposition between existence and non-existence, being and nothingness. Whereas it is crucial to pre-modern dualisms such as that of Augustine's kingdom of heaven versus kingdom of earth to sustain an unresolvable tension between the terms of the duality - between, for example, ideal and reality - the modern ontology of existence radicalizes the oppositionality between such terms by evacuating their content and context, in the process eliminating any hierarchical, graded links between the terms of the duality such that they may collapse in upon themselves and be rendered dialectically equivalent: 'by their very contradictions they are made to correspond'. ${ }^{73}$ Melville pinpoints here the 'genius' of American culture: its ability to fuse or 'aufheben' the contradictions between ideal and reality, between what it believes and what it does, in the very process of intensifying them. As in the case of Nietzschean slave morality, it is crucial to this logic that the act of negation be prior to that of affirmation: that 'all the terms be negative' and that the ideal define itself through its antithesis. As Sacvan Bercovitch has described this logic:

Symbolic analysis confines us to the alternatives generated by the symbol itself. It may suggest unexpected meanings, but only within a fixed bipolar system. Since every symbol unites opposites, or represents them as the same thing, we can understand what is being represented only by measuring it against its opposite, or by placing it within a series of comparable and related oppositions. Thus the search for meaning is at once endless and self-enclosed. Any possibility we propose invites a host of different possibilities, all of these inherent in the symbol. Any resolution of opposites we discover is implicit in the dualisms with which we began. ${ }^{74}$

Bercovitch describes here a kind of thinking that he sees as characteristic of American culture from the 17th-century Puritans, with their equation of heaven and earth, promise and fulfillment, in the form of God's new chosen people, to Jonathan Edwards's post-millennialist reconciliation of historical and sacred time (as reflected in Lockean empiricism and Calvinistic other-worldliness, respectively), to Emerson's pragmatist resolution of Jacksonian America's cultural chauvinism and Swedenborgian transcendentalism. But he could just as well be talking about American critics' uses of Derridean deconstruction, in which the most abstract, other-worldly notion of 'theory', one based on an antihumanistic and de-naturalized view of the workings of language, is conjoined to the most 'this-worldly' social and political goals. What impels such theory is the urge to ontologize; and what masks the nature of that urge is a radical epistemological skepticism which claims to affirm, or 'decide', nothing. But to affirm nothing, a genuinely performative ethics demands, is to affirm Nothing. It is to let in ontology through the back 
door, all the while barring the front door to any finitely grounded, culturally specific, evaluative criticism.

Here care must be taken to avoid the fallacy of assuming that Derrida's work is representative of the second generation of French structuralists. It is true that his work articulates with the highest degree of philosophical self-consciousness the Heideggerian sources of his generation's perspective - more so, for example, than the works of Foucault and Lacan, not to mention those of Deleuze and Lyotard. ${ }^{75}$ But the impression needs to be sharply qualified: to be put, in Heideggerian terms, 'under erasure'. For to the extent that it is true, it is true from the perspective of literary theorists in this country, and even from that perspective, only to a limited extent. It is not true in any sense from a French perspective. On the contrary, although Derrida has been for almost 30 years the single greatest philosophical influence on literary theory in the United States, he has been neither an especially influential nor representative figure within his own country. It would appear that what does not appeal entirely to French intellectuals about Derrida's work does appeal quite hugely to American literary theorists: his ability to incorporate a Romanticist, Germanic habit of thought within an intensely analytical, French practice of language. In Negative Dialectics, Theodor Adorno characterized Heideggerian philosophy as 'a second reprise of the old philosophies of the Absolute, their first reprise having been post-Kantian idealism'. ${ }^{76}$ Could it be that American poststructuralism and postmodernism, if not a third reprise, are nonetheless haunted by the ghost of such an Absolute? Is it possible that Derrida's influence in this country is an indication less of the ability of American critics to assimilate French styles of thinking and writing than of a characteristically American resistance to such styles?

Literary theorists in this country, by endorsing Heidegger and Derrida's self-serving accounts of their writings as assaults on the entire history of western philosophy, and by failing to judge them critically as outgrowths of that history, have not only obscured the sources from which an understanding of language as a concrete social and cultural form of action can be recovered. They have also helped to sustain the central tenet of American literary theory since the 1960s: that there is such a thing as a 'western philosophical tradition' that we may maneuver ourselves, through an endless series of linguistic coinages and 'erasures', on the 'other' side of. My claim is that to the extent that there is such an other side, we are already on it, and that we fundamentally misunderstand our situation if we regard it as 'other' to the western philosophical tradition.

English Department, University of Oklahoma, Norman, OK, USA 


\section{Philosophy \& Social Criticism 30 (2)}

\section{Notes}

1 There are, of course, many references to the oddity of literary critics' use of the term 'theory'. For example, in Ferdinand de Saussure (Ithaca, NY: Cornell University Press, 1986), Jonathan Culler remarks on 'that strange realm called "theory"' (p. 10). But there is to my knowledge no extended, substantive discussion of the displacement of the term 'philosophy' by 'theory' by American literary theorists as it has taken shape in recent decades. In contrast, François Dosse, in his comprehensive history of French structuralism, History of Structuralism, 2 vols, trans. Deborah Glassman (Minneapolis: University of Minnesota Press, 1997), emphasizes just this point in his discussion of the tension in France between philosophy and the social sciences: 'By renewing its problematic, philosophy could socialize the social sciences, which had the advantage of using a readable, rigorous, and formalizable discourse. The operation was so successful that philosophers refrained from carrying it out in the name of philosophy, which many at the time considered dead; instead, they substituted the word theory' (pp. 297-98). See also pp. 259, 330-32.

2 In 'Signature Event Context', trans. Samuel Weber and Jeffrey Mehlman, in Limited Inc. (Evanston, IL: Northwestern University Press, 1988), Derrida identified 'the system of interpretation' he was critiquing with 'the history of philosophy', asserting that he did not 'believe that a single counterexample [to such system of interpretation] can be found in the entire history of philosophy as such' (p. 3). In the preface to Of Grammatology, Derrida notes that his assertions in the following pages 'demand that reading should free itself, at least in its axis, from the classical categories of history - not only from the categories of the history of ideas and the history of literature but also, and perhaps above all, from the categories of the history of philosophy' (p. lxxxix); Of Grammatology, trans. Gayatri Chakravorty Spivak (Baltimore, MD: Johns Hopkins University Press, 1976). In Dissemination, trans. Barbara Johnson (Chicago, IL: University of Chicago Press, 1981), Derrida goes so far as to link together Plato, Rousseau and Saussure in one, all-unifying proper name, in order to signify a common adherence to a metaphysics of presence: 'Plato-Rousseau-Saussure' (p. 110).

3 The New Critics were influenced by Benedetto Croce's Aesthetic: A Science of Expression, trans. Douglas Ainslie (New Brunswick, NJ: Transaction Publishers, 1909), which demarcates aesthetic intuition from the categories of 'the true and the good'. See also his Guide to Aesthetics, trans. Patrick Romanell (Indianapolis, IN: Hackett, 1965), p. xxvii, as well as W. K. Wimsatt and Cleanth Brooks's Literary Criticism: A Short History (New York: Random House, 1957); Monroe C. Beardsley's Aesthetics: From Classical Greece to the Present (Tuscaloosa: University of Alabama Press, 1966); Walter Jackson Bate's Criticism: The Major Texts (New York: Harcourt Brace Jovanovich, 1970) and Vincent Leitch's American Literary Criticism: From the 30s to the 80s (New York: Columbia University Press, 1988).

4 'What Americans call poststructuralism existed even before the structural paradigm waned. In fact, it was contemporary with its triumph': Dosse, 
History, II, p. 17. See also Sunil Khilani, Arguing Revolution: The Intellectual Left in Postwar France (New Haven, CT: Yale University Press, 1993) and Tony Judt, Past Imperfect: French Intellectuals, 1944-1956 (Berkeley: University of California Press, 1992). In Deconstructive Criticism (New York: Columbia University Press, 1983), Vincent Leitch comments, 'American deconstructors largely bypass examinations of structuralism (and of its "sign") since it never really established a significant foothold in America' (pp. 100-1). In Cultural Criticism, Literary Theory, Poststructuralism (New York: Columbia University Press, 1992), Leitch notes: 'Given its commitments, poststructuralist cultural criticism is suspicious of literary formalism' (p. 9). Such a perspective contrasts strikingly with Derrida's who, criticizing Saussure in Positions, trans. Alan Bass (Chicago, IL: University of Chicago Press, 1981), asserts, 'The theme of the arbitrary, thus, is turned away from its most fruitful paths (formalization) toward a hierarchizing teleology' (p. 21). On the misconceptions surrounding the politics of New Criticism, see Morris Dickstein, 'Ralph Ellison, Race, and American Culture', Raritan: A Quarterly Review (Spring, 1999): 30-50.

5 In The Literary Absolute: The Theory of Literature in German Romanticism, trans. Philip Barnard and Cheryl Lester (Albany: State University of New York Press, 1988), Phillippe Lacoue-Labarthe and Jean-Luc Nancy, two authors closely associated with Derrida, comment on the collaboration of German romantics on their journal, the Athenaeum, as follows: 'At no point does one discern the least departure from this nearly two-hundredyear-old form on the part of what calls itself "avant-garde" today. The Athenaeum is our birthplace' (p. 8); see also pp. 9-12, 29, 34-5, 105-8, 124. See, too, Peter Dews, Logics of Disintegration: Post-Structuralist Thought and the Claims of Critical Theory (London: Verso, 1987), pp. 19-25, 115-50; Gillian Rose, 'Of Derrida's Spirit', in David Wood (ed.), Of Derrida, Heidegger, and Spirit (Evanston, IL: Northwestern University Press, 1993), pp. 56-72; Luc Ferry, The System of Philosophies of History. Political Philosophy, Vol. II, trans. Franklin Philip (Chicago, IL: University of Chicago Press, 1992), pp. 1-74. See also note 51.

6 On structuralists' early, often losing battles with the French academy, see Dosse, History, I, pp. 59-70, 166-87. On the breakthroughs it achieved beginning in the 1960s, see Vincent Descombes, Modern French Philosophy, trans. L. Scott-Fox and J. M. Harding (Cambridge: Cambridge University Press, 1980), pp. 75-109; Jean-Marie Benoist, The Structural Revolution (New York: St Martin's Press, 1975), pp. 1-30.

7 On the influence of the events of 1968, see Alice A. Jardine and Anne M. Menke (eds), Shifting Scenes: Interviews on Women, Writing, and Politics in Post-68 France (New York: Columbia University Press, 1991), pp. 1-16. On Barthes's relation to Sartre, see Roland Barthes, Criticism and Truth, trans. Katrine Picher Keuneman (Minneapolis: University of Minnesota Press, 1987), pp. 8, 12. On Lévi-Strauss's relation to Sartre, see Claude LéviStrauss, The Elementary Structures of Kinship, trans. James Harle Bell, John Richard von Sturmer and Rodney Needham (Boston, MA: Beacon Press, 1969), pp. 108-9. On Sartre's role in general in relation to structuralism and related issues, see Dominick LaCapra, A Preface to Sartre 


\section{Philosophy \& Social Criticism 30 (2)}

(Ithaca, NY: Cornell University Press, 1978); David E. Cooper, Existentialism (Oxford: Blackwell, 1990), pp. 197-205.

8 Lévi-Strauss, Elementary Structures, p. 109.

9 Dosse, History, I, pp. xxiii-xxiv, 298-9; Gianni Vattimo, The Adventure of Difference: Philosophy After Nietzsche and Heidegger, trans. Cyprian Blamires (Baltimore, MD: Johns Hopkins University Press, 1993), pp. 158-86.

10 Manfred Frank, What is Neostructuralism?, trans. Sabine Wilke and Richard Gray (Minneapolis: University of Minnesota Press, 1988), pp. 20-1.

11 On the centrality of the work of Heidegger to structuralism and related movements, see Vincent Descombes, The Barometer of Modern Reason: On the Philosophies of Current Events, trans. Stephen Adam Schwartz (New York: Oxford University Press, 1993), pp. 108-25, 156-7; Rodolphe Gasche, The Tain of the Mirror (Cambridge, MA: Harvard University Press, 1986), pp. 82-8, 111-20, 181-3; Rodolphe Gasche, Inventions of Difference (Cambridge, MA: Harvard University Press, 1994), pp. 111-18, 130-41.

12 On the influence of Hegelian dialectics, see Gasche, Tain of the Mirror, pp. 19-65, 138-41; Vattimo, Adventure, pp. 30-5, 159-80; Simon Critchley, The Ethics of Deconstruction: Derrida and Levinas (West Lafayette, IN: Purdue University Press, 1992), pp. 1-29. On the influence of Husserlian phenomenology, see Descombes, Modern French Philosophy, pp. 3-4, 140-6; Critchley, Ethics, pp. 54-5, 64-5; Dews, Logics, pp. 5-15.

13 On the revolt against neo-Kantianism and return to Hegel, see Mark Poster, Existential Marxism in Postwar France (Princeton, NJ: Princeton University Press, 1975), pp. 3-71; Stuart H. Hughes, Between Commitment and Disillusion: The Obstructed Path and the Sea Change, 1930-1965 (Middletown, CT: Wesleyan University Press, 1975[1966]), pp. 105-17, 173-80; Jacques Derrida, Margins of Philosophy, trans. Alan Bass (Chicago, IL: University of Chicago Press, 1982), pp. 115-16.

14 Judith Butler, Subjects of Desire: Hegelian Reflections in Twentieth-Century France (New York: Routledge, 1997), p. 62.

15 Descombes, Modern French Philosophy, p. 21.

16 On the influence of Kojève's seminars, see Butler, Subjects of Desire, pp. 61-83, 92-9; Allan Bloom, 'Introduction', in Alexandre Kojève, Introduction to the Reading of Hegel: Lectures on the Phenomenology of the Spirit, trans. James H. Nichol, Jr (Ithaca, NY: Cornell University Press, 1969), pp. vii-xii; Michael Roth, Knowing and History: Appropriations of Hegel in Twentieth-Century France (Ithaca, NY: Cornell University Press, 1988), pp. 81-146.

17 Gilles Deleuze, 'Review of Jean Hyppolite', in Jean Hyppolite, Logic and Existence, trans. Leonard Lawlor and Amit Sen (Albany: State University of New York Press, 1997), p. 193; Roland Barthes, The Grain of the Voice: Interviews, 1962-1980, trans. Linda Coverdale (Berkeley: University of California Press, 1985), p. 249; Roland Barthes, Writing Degree Zero, trans. Annette Lavers and Colin Smith (New York: Hill \& Wang, 1968), pp. 1, 5, 20.

18 Descombes, Modern French Philosophy, pp. 37-8. On the surrealists and their importance to the Tel Quel group, see Maurice Nadeau, The History 
of Surrealism, trans. Richard Howard (Cambridge, MA: Harvard University Press, 1989), p. 201.

19 On the relation between deconstruction and aestheticism, as well as French symbolism, see Julian Wolfreys (ed.), The French Connections of Jacques Derrida (Albany: State University of New York Press, 1999), pp. 1-70, 175-210.

20 Friedrich Nietzsche, The Will to Power, trans. Walter Kaufmann and R. J. Hollingdale (New York: Vintage, 1968), p. 276.

21 Martin Heidegger, Being and Time, trans. John Macquarrie and Edward Robinson (San Francisco, CA: Harper \& Row, 1962), p. 444; Martin Heidegger, Sein und Zeit, Gesamtausgabe, vol. II (Frankfurt am Main: V. Klostermann, 1977), p. 518. On Germany's traditional lack of political avenues of expression, see M. S. Silk and J. P. Stern, Nietzsche on Tragedy (Cambridge: Cambridge University Press, 1981), p. 299. On Germany's crisis of historicism during the Weimar period, especially with reference to Heidegger, see Charles R. Bambach, Heidegger, Dilthey, and the Crisis of Historicism (Ithaca, NY: Cornell University Press, 1995); Jeffrey Herf, Reactionary Modernism: Technology, Culture, and Politics in Weimar and the Third Reich (Cambridge: Cambridge University Press, 1984); Michael E. Zimmerman, Eclipse of the Self: The Development of Heidegger's Concept of Authenticity (Athens: Ohio University Press, 1981), pp. 118-19, 166-7, 179-83, 201-3.

22 Roth, Knowing and History, p. 67.

23 Keith A. Reader, Intellectuals and the Left in France since 1968 (New York: St Martin's Press, 1987); Khilnani, Arguing Revolution, pp. 3-120; Ronald Hayman, Sartre: A Biography (New York: Carroll \& Graf, 1987), pp. 186-7, 336-7.

24 Quoted in Dosse, History, I, p. 330.

25 The obscure Calvinist philosopher was, according to Rene Wellek's $A$ History of Modern Criticism 1750-1950, Vol. VI, American Criticism 1900-1950 (New Haven, CT: Yale University Press, 1986), p. 161, 'Rudolf Golclenius' (1547-1628). See also Joseph Owens, 'The Doctrine of Being in the Aristotelian Metaphysics - Revisited', in Parviz Morewedge (ed.), Philosophies of Existence (New York: Fordham University Press, 1982), p. 35; and Alasdair MacIntyre, 'Ontology', in Paul Edwards (ed.), The Encyclopedia of Philosophy, vol. 5 (New York: Macmillan, 1967), p. 542.

26 Friedrich Nietzsche, On the Genealogy of Morals, in Basic Writings of Nietzsche, trans. Walter Kaufmann (New York: Random House, 1968), p. 488; Friedrich Nietzsche, Zur Genealogie der Moral: Eine Streitschrift (Leibzig: Wilhelm Goldmann Verlag, 1887), p. 41.

27 See Paul Seligman, 'Being and Forms in Plato', in Morewedge (ed.), Philosophies of Existence, p. 18; Charles Kahn, 'Why Existence Does Not Emerge as a Distinct Concept in Greek Philosophy', in ibid., pp. 7-17; Etienne Gilson, Being and Some Philosophers (Toronto: Pontifical Institute of Mediaeval Studies, 1952), p. 119.

28 See Heidegger, Being and Time, p. 30; Heidegger, Sein und Zeit, pp. 3-14; Heido A. Oberman, Luther: Man Between God and the Devil, trans. Eileen Walliser-Schwarzbartl (New York: Doubleday, 1992), pp. 120-1, 274-5; 
Friedrich Richter, Martin Luther and Ignatius Loyola (Westminster, MD: The Newman Press, 1960), pp. 10, 88; Zimmerman, Eclipse, p. 19; Bambach, Heidegger, Dilthey, and the Crisis of Historicism, pp. 199-201.

29 See Jacques Derrida, 'How to Avoid Speaking: Denials', in Sanford Budick and Wolfgang Iser (eds), Languages of the Unsayable: The Play of Negativity in Literature and Literary Theory (New York: Columbia University Press), pp. 1-34; Jacques Derrida, 'Post-Scriptum: Aporias, Ways and Voices', in Harold Coward and Toby Foshay (eds), Derrida and Negative Theology (New York: State University of New York Press, 1992), pp. 283-323; Jacques Derrida, 'Faith and Knowledge', in Jacques Derrida and Gianni Vattimo (eds), Religion: Cultural Memory in the Present (Stanford, CA: Stanford University Press, 1998, pp. 1-78.

30 Martin Heidegger, Kant and the Problem of Metaphysics, trans. Richard Taft (Bloomington: Indiana University Press, 1997), p. 161; Martin Heidegger, Kant und das Problem der Metaphysik, Gesamtausgabe, Vol. III (Frankfurt am Main: V. Klostermann, 1991), p. 230. Leibniz's question appears in 'The Principles of Nature and Grace, Based on Reason' [1714], in Philip P. Wiener (ed.), Selections (New York: Charles Scribner, 1951), p. 527. The sentence following the question, 'For nothing is simpler and easier than something' (p. 527), clearly indicates the non-ontological, determinedly metaphysical, and 'non-modern' sense in which Leibniz understood the question. For discussions of the question by Heidegger, see 'Nihilism as Determined by the History of Being', in David Farrell Krell (ed.), Nietzsche, Vol. IV of 4 vols, trans. Joan Stambaugh, David Farrel Krell, and Frank A. Capuzzi (San Francisco, CA: Harper, 1987), p. 208; Martin Heidegger, Nietzsche, Zeiter Band, Gesamtausgabe, Vol. VI.2 (Frankfurt am Main: V. Klostermann, 1997), pp. 312-13; Martin Heidegger, 'What is Metaphysics?', in David Farrell Krell (ed.), Basic Writings (New York: Harper \& Row, 1977), pp. 91-112; Martin Heidegger, 'Was ist Metaphysik?', Gesamtausgabe, Vol. IX (Frankfurt am Main: V. Klostermann, 1976), pp. 103-22. Martin Heidegger, Introduction to Metaphysics, trans. Ralph Manheim (Garden City, NY: Doubleday, 1961), pp. 1-42; Martin Heidegger, Einfuhrung in Die Metaphysik, Gesamtausgabe, Vol. XL (Frankfurt am Main: V. Klostermann, 1983), pp. 3-55; William McNeill (ed.), Pathmarks (Cambridge: Cambridge University Press, 1998), pp. 289, 317; Martin Heidegger, Wegmarken (Frankfurt am Main: V. Klostermann, 1976), pp. 210-11, 248-9. In Heidegger, Nietzsche, David Krell comments on the importance of this issue in Heidegger's works, early and late, as follows: 'Study of [Heidegger's] later texts discloses the lasting quality of the issue of ground and nullity. Such study makes it impossible to assent to that interpretation of Heidegger's career which asserts that the problem of the nothing pertains to an "existentialist" phase that is soon tranquilized into "releasement" by "thankfulness to Being"' (pp. 284-5). In his Essay on the Origin of Language (London: Dent, 1976), Locke remarks on the metaphysical implications of essentia as follows: 'Essence may be taken for the being of anything whereby it is what it is. And thus the real internal, but generally (in Substances) unknown, constitution of things, whereon their discoverable qualities depend, may be called their 
essence. This is the proper original signification of the word, as is evident from the formation of it: essentia, in its primary notation, signifying properly being' (p. 238). From the standpoint of 20th-century French philosophy, Bergson, whose work Derrida has expressed much appreciation for, can be seen to anticipate the (ontological) 'turn' to language. As Descombes says in Modern French Philosophy, 'Leibniz's statement of the metaphysical problem [which is precisely not "metaphysical" from my standpoint] why is there something, rather than nothing? - clearly shows that the metaphysician sets nothing on a par with something, or even accords it a certain priority. But in reality, explains Bergson, this nothing is an effect of language' (p. 25). Robert Bernasconi in The Question of Language in Heidegger's History of Being (Atlantic Highlands, NJ: Humanities Press, 1991) aptly comments that in addressing the Question of Being, 'There is no "why", only the "that"' (p. 8).

31 Karl Lowith, Martin Heidegger: European Nihilism, trans. Gary Steiner (New York: Columbia University Press, 1995), p. 51; Heidegger, 'What is Metaphysics?' in Krell (ed.), Basic Writings, p. 110; Heidegger, 'Was ist Metaphysik?', p. 120. Ens in Latin is singular in number; but it is not translated that way by Heidegger. The translation of 'beings' is from a standard translation of Heidegger's German, not from the original Latin.

32 For useful discussions of nihilism in this regard, see Michael Allen Gillespie, Nihilism Before Nietzsche (Chicago, IL: University of Chicago Press, 1995) and Frederick C. Beiser, The Fate of Reason: German Philosophy from Kant to Fichte (Cambridge, MA: Harvard University Press, 1987), pp. 30-1, 81-5.

33 Heidegger, Being and Time, p. 444; Heidegger, Sein und Zeit, pp. 517-18.

34 See Oberman, Luther, pp. 121, 118-19, 159-61, 169-70. With reference especially to Calvin, see Michael Walzer, The Revolution of the Saints: A Study in the Origins of Radical Politics (New York: Atheneum, 1974), pp. 7, 26, 154-5.

35 Condillac discusses the term 'reflexion' in An Essay on the Origin of Human Knowledge (1756), trans. Thomas Nugent (Delmar, NY: Scholars' Facsimiles \& Reprints, 1971), pp. 59-60, 119. Herder discusses the term 'Besonnenheit' in his Essay on the Origin of Language, in Herder and Rousseau, On the Origin of Language: Two Essays, trans. John H. Moran and Alexander Gode (Chicago, IL: University of Chicago Press, 1966), pp. 112-25. Locke discusses the term 'reflection' in An Essay Concerning Human Understanding, p. 46. In his Herder's Aesthetics \& the European Enlightenment (Ithaca, NY: Cornell University Press, 1991), Robert Norton comments on Herder's use of 'Besonnenheit' as follows: 'Herder's neologism "Besonnenheit", which I take as the attempt to translate the French or Latinate "reflection" (this is how Hamann - as reliable an authority as any - understood the term, for Herder actually uses the word "Reflexion" much more often than "Besonnenheit") has stirred considerable disagreement and controversy in the scholarly literature as to its precise meaning. But in the review of Herder's treatise in the Allgemeine Deutsche Bibliotek of 1773, the reviewer equated "Besonnenheit" quite simply with "reason": "Man is distinguished from all other animals by an articulated language which is 
used deliberately and arbitrarily; hence, its origin must be sought in the characteristic difference of man." This is reason, or as the author prefers to call it, "Besonnenheit", according to which human cognitive power expresses itself in larger realms, in a finer organization and more clearly' (p. 113).

36 Culler, Ferdinand de Saussure, pp. 28-39.

37 Gasche, The Tain of the Mirror, p. 292.

38 Vattimo, The Adventure of Difference, p. 138.

39 Judith Butler, Excitable Speech: A Politics of the Performative (New York: Routledge, 1997), pp. 1-2.

40 Jacques Derrida, Points Interviews, 1974-1994, trans. Peggy Kamuf et al. (Stanford, CA: Stanford University Press, 1995), p. 212; see also Derrida, Of Grammatology, p. 10; Jacques Derrida, De la Grammatologie (Paris: Les Editions de Minuit, 1967), p. 21; Wood (ed.), Of Derrida, Heidegger, and Spirit, pp. 1-2.

41 Jacques Derrida, Writing and Difference, trans. Alan Bass (Chicago, IL: University of Chicago Press, 1978), p. 311; see also Heidegger, Introduction to Metaphysics, p. 34; Heidegger, Einfuhrung in Die Metaphysik, pp. 45-6.

42 Deleuze, 'Review of Jean Hyppolite', in Hyppolite, Logique et Existence, pp. 192-3.

43 Peter Dews, The Limits of Disenchantment: Essays on Contemporary European Philosophy (London: Verso, 1995), p. 141.

44 In The Basic Problems of Phenomenology, trans. Albert Hofstader (Bloomington: Indiana University Press, 1982), p. 12; Die Grundprobleme der Phanomenologie, Gesamtausgabe, vol. 24 (Frankfurt am Main: V. Klostermann, 1975), p. 16, Heidegger says, 'It can be shown historically that at bottom all the great philosophies since antiquity more or less explicitly took themselves to be, and as such sought to be, ontology' (p. 12). As for Derrida, the western tradition is repeatedly characterized in terms of the pervasive influence of a 'metaphysics of presence'. As he says in 'Signature Event Context', in Limited Inc., 'I do not believe that a single counterexample can be found in the entire history of philosophy' (p. 3).

45 I use this phrase, 'the linguistic turn', the title of a collection of essays edited by Richard Rorty that was published in 1967, to refer to both AngloAmerican and continental traditions of philosophy.

46 I refer to the numerous passages in Heidegger's late works in which he refers to Being as having itself willed or 'sent' the indications of its own absence.

47 See note 5; and Jonathan Loesberg, Aestheticism and Deconstruction: Pater, Derrida, and de Man (Princeton, NJ: Princeton University Press, 1991), pp. 3-10, 143-50.

48 Jerome J. McGann, The Romantic Ideology: A Critical Investigation (Chicago, IL: University of Chicago Press, 1983), pp. 21-39.

49 Immanuel Kant, Critique of Judgment, trans. Werner S. Pluhar (Indianapolis, IN: Hackett Publishing, 1987), pp. 106, 121.

50 Tzvetan Todorov, Theories of the Symbol, trans. Catherine Porter (Ithaca, NY: Cornell University Press, 1982), p. 287.

51 In the Appendix to The Postmodern Condition: A Report on Knowledge, 
trans. Geoffrey Bennington and Brian Massumi (Minneapolis: University of Minnessota Press, 1984), Jean-François Lyotard says, 'A work can become modern only if it is first postmodern' (p. 79). In his Introduction to Literary Hermeneutics, trans. Martha Woodmansee (Cambridge: Cambridge University Press, 1995), Peter Szondi traces romanticist views of textuality to the Reformation (pp. 10, 30, 126). See also Andrew Bowie, From Romanticism to Critical Theory: The Philosophy of German Literary Theory (London: Routledge, 1997) pp. 4, 13-16; Ferry, System of Philosophies of History, Vol. 2, pp. 1-31; Dews, Limits of Disenchantment, pp. 115-48. See also note 5.

52 Khilnani, Arguing Revolution, p. 178.

53 Heinrich Heine, Religion and Philosophy in Germany, trans. John Snodgrass (Albany: State University of New York Press, 1986), pp. 59-60.

54 Lewis White Beck, Early German Philosophy: Kant and his Predecessors, (Bristol: Thoemmes Press, 1996), pp. 244-5, 424-30.

55 H. Stuart Hughes, Consciousness and Society: The Reorientation of European Social Thought, 1890-1930 (New York: Knopf, 1958), p. 184.

56 On Kant's project in the first and second Critiques to lay the basis for a 'metaphysics of metaphysics', or new form of ontology, see The Critique of Practical Reason, trans. Lewis White Beck (Indianapolis, IN: Bobbs Merrill, 1956), pp. 5, 50: 'Now is explained the enigma of the critical philosophy, which lies in the fact that we must renounce the objective reality of the supersensible use of the categories in speculation and yet can attribute this reality to them in respect to the objects of pure practical reason. I hold open for speculative reason the place which for it is vacant, i.e., the intelligible, in order to put the unconditioned in it. Pure practical reason now fills this vacant place with a definite law of causality in an ancient world (causality through freedom.'

57 See Frederick C. Beiser, The Sovereignty of Reason: The Defense of Rationality in the Early English Enlightenment (Princeton, NJ: Princeton University Press, 1996), pp. 24-30.

58 Heine, Religion and Philosophy in Germany, p. 158.

59 Fritz Ringer, The Decline of the German Mandarins: The German Academic Community, 1890-1933 (Hanover, NH: Wesleyan University Press, 1990); George L. Mosse, The Crisis of German Ideology: Intellectual Origins of the Third Reich (New York: Howard Fertig, 1964), pp. 52-67; Pierre Bourdieu, The Political Ontology of Martin Heidegger, trans. Peter Collier (Stanford, CA: Stanford University Press, 1991), pp. 55-69.

60 Quoted in Jacques Derrida, Of Spirit: Heidegger and The Question, trans. Geoffrey Bennington and Rachel Bowlby (Chicago, IL: University of Chicago Press, 1989), p. 69.

61 Paul Oskar Kristeller, Renaissance Thought and Its Sources (New York: Columbia University Press, 1979), pp. 23-5. The term Humanismus was coined in the early 19th century, but goes back to the Latin Humanista, coined during the Renaissance (pp. 21-32).

62 Aarsleff has argued in From Locke to Saussure, for example, that 'the contrast and conflict between so-called empiricism and rationalism is a 19 th-century invention, advanced in the context of a conservative reaction 
against contemporary philosophical doctrines, in the interest of a characteristic Victorian ideology' (p. 283). See also P. U. Hohendahl (ed.), A History of German Literary Criticism, 1730-1980 (Lincoln: University of Nebraska Press, 1988), pp. 14-15, 38; Dorinda Outram, The Enlightenment (Cambridge: Cambridge University Press, 1995); James Schmidt (ed.), What is Enlightenment? Eighteenth-Century Answers and TwentiethCentury Questions (Berkeley: University of California Press, 1996), pp. 1-44; Raymond Williams, Culture and Society: Coleridge to Orwell (New York: Columbia University Press, 1958), pp. xiii-xviii; Terry Eagleton, The Function of Criticism from the Spectator to Poststructuralism (London: Methuen Press, 1984), pp. 10-22; Peter Gay, The Enlightenment: The Rise of Modern Paganism (New York: W. W. Norton, 1966); Peter Gay, The Enlightenment: An Interpretation. The Science of Freedom (New York: W. W. Norton, 1969).

63 Ludwig Wittgenstein, Philosophical Investigations, trans. G. E. M. Anscombe (Oxford: Basil Blackwell, 1972), p. 42, sec. 89: p. 44, sec. 94; Friedrich Nietzsche, 'Attempt at a Self-Criticism': Preface to The Birth of Tragedy (1886), in Walter Kaufmann (ed.), Basic Writings of Nietzsche (New York: Random House, 1968), pp. 3-146; Friedrich Nietzsche, 'Versuch Einer Selbstkritik', in Die Geburt der Tragodie aus dem Geiste der Musik (Leipzig: Wilhelm Goldmann Verlag, 1895), p. 16.

64 The basis of those distortions, which include an almost exclusive reliance on notes, discarded drafts, and other writings of Nietzsche collected and published under the title The Will to Power, by Nietzsche's sister, Elisabeth Forster, have been admirably documented by David Farrell Krell in 'Introduction to the Paper Edition: Heidegger Nietzsche Nazism', in Heidegger, Nietzsche, pp. ix-xxvii. More fundamentally, however, Heidegger interprets Nietzsche's notions of the will to power and the eternal return of the same from his own highly 'ontological' or anti-metaphysical perspective, whereas in fact, as Karl Lowith has commented in Richard Wolin (ed.), Martin Heidegger: European Nibilism, trans. Gary Steiner (New York: Columbia University Press, 1995), 'To the extent that in Nietzsche there can be any talk of an ontological questioning in the rigorous sense, that which he occasionally calls 'Being' and for the most part calls 'the total character of life' is not essentially related to the Nothing but instead is the Being which is eternally the same and which as a becoming both annihilates and creates, though to the extent that it is a Being which eternally becomes it is simply affirmative' (p. 110).

65 Richard Rorty, Essays on Heidegger and Others. Philosophical Papers Volume 2 (Cambridge: Cambridge University Press, 1991), pp. 50-65.

66 Wittgenstein, Philosophical Investigations, p. 47, sec. 108.

67 Heidegger, Kant and the Problem of Metaphysics, pp. 201-3; Heidegger, Kant und das Problem der Metaphysik, pp. 287-91.

68 Lowith, in Wolin (ed.), Martin Heidegger: European Nibilism, p. 133.

69 Nietzsche, Beyond Good and Evil, in Kaufmann (ed.), Basic Writings of Nietzsche, pp. 373-4; Friedrich Nietzsche, Jenseits von Gut und Bose: Vorspiel einer Philosophie der Zukunft (Munich: Wilhelm Goldmann Verlag, 1886), pp. 138-9. 
70 Szondi, Introduction to Literary Hermeneutics, p. 68.

71 Jeffrey Herf, Reactionary Modernism: Technology, Culture, and Politics in Weimar and the Third Reich (Cambridge: Cambridge University Press, 1984), pp. 105-15. Herf points out, however, that Heidegger was atypical of reactionary modernists in that 'he was not able or willing to reconcile his version of antimodernist protest with modern technology' (p. 109).

72 Jean-François Lyotard, Heidegger and the Problem of 'the Jews', trans. Andreas Michel and Mark S. Roberts (Minneapolis: University of Minnesota Press, 1990), p. 73.

73 Herman Melville, Pierre, or the Ambiguities (Evanston, IL: Northwestern University Press, 1995), p. 212. See also pp. 204-15, 289-94.

74 Sacvan Bercovitch, The American Jeremiad (Madison: University of Wisconsin Press, 1978), pp. 177-8.

75 In Of Grammatology, Derrida says, 'One must go by way of the question of being as it is directed by Heidegger and by him alone, at and beyond onto-theology, in order to reach the rigorous thought of that strange nondifference [i.e., Derridean differance], and in order to determine it correctly'; Derrida Of Grammatology, p. 10; Derrida, De la Grammatologie, p. 21. There are, of course, important differences between Heideggerian and Derridean thought that must not be ignored in assessing the development of poststructuralism and postmodernism. Yet the recognition and acknowledgement of such differences should not be used as a means of obfuscating or disregarding the far more important lines of continuity and paths of influence between them. Few philosophers in the history of western philosophy who fashion themselves independent and original thinkers have done more to acknowledge the centrality of a previous philosopher's work to his own than Derrida has done, very consistently over a period of 30 years, with Heidegger's. Yet many theorists and critics influenced by Derrida have been oddly anxious to dissociate the work of the two. Leitch, in Deconstructive Criticism, for example, attempts to distinguish between Heideggerian destruction and Derridean deconstruction on the basis of the latter's more consuming preoccupation with 'language' rather than 'being' (pp. 84-5). In the terms that I have sketched in this study, this is to confuse a pre-modern metaphysics of presence with the modern ontology of reflection, and to disregard the fact that the 'turn' to language, in both Derrida and the late Heidegger, is simultaneously an encounter with the Question of Being. See Heidegger, 'The Origin of the Work of Art', in Kaufmann (ed.), Basic Writings, p. 73; and Jacques Derrida, Writing and Difference, p. 77.

As for the term 'deconstruction', Derrida on occasion uses it as synonym for Heideggerian 'destruction'; see Of Spirit, pp. 5, 16. 'Derrida', as Ernst Behler says, 'through the insertion of the syllable con in the Heideggerian 'destruction' has, at least in the French language and fortuitously in English, more clearly expressed Heidegger's intended meaning'; Ernst Behler, Confrontations: Derrida, Heidegger, Nietzsche, trans. Steven Taubeneck (Stanford, CA: Stanford University Press, 1991), pp. 29-30. Alan Bass makes a similar point concerning the relation between Derrida's term 'differance' and Heidegger's ontico-ontological difference. In Positions, Derrida says, 'What I have attempted to do would not have been possible 
Philosophy \& Social Criticism 30 (2)

without the opening of Heidegger's questions' (p. 9). See also Richard Kearney, 'Deconstruction and the Other', in Dialogues with Contemporary Continental Thinkers (Manchester: Manchester University Press, 1984), 'My philosophical formation owes much to the thought of Hegel, Husserl, and Heidegger. Heidegger is probably the most constant influence, and particularly his project of “overcoming” Greek metaphysics' (p. 109). On Heidegger's importance to the poststructuralist tradition, see Gasche, Inventions of Difference, pp. 6, 82-9, 111-20; Timothy Clark, Derrida, Heidegger, Blanchot: Sources of Derrida's Notion and Practice of Literature (New York: Cambridge University Press, 1989), pp. 10-63. To stress the centrality of Heidegger to poststructuralism is also to stress the importance of Husserlian phenomenology as a principal object of critique by poststructuralists. But as its name indicates, poststructuralism also defines itself in opposition to Saussurean semiotics. On the relation between Husserl and Heidegger, see Hubert Dreyfus, Being-in-the-World: A Commentary on Heidegger's Being and Time, Division I (Cambridge, MA: MIT Press), pp. 2-4, 6-7, 49, 85, 267-8.

76 Theodor W. Adorno, Negative Dialectics, trans. E. B. Ashton (New York: Continuum, 1966), p. 62. 